\title{
PREVALENCE OF EARLY SPINAL DEFORMITY IN CHILDREN WITH GMFCS V CEREBRAL PALSY
}

\author{
PREVALÊNCIA DA DEFORMIDADE ESPINHAL PRECOCE EM CRIANÇAS COM PARALISIA \\ CEREBRAL GMFCS V
}

\section{PREVALENCIA DE DEFORMIDAD ESPINAL TEMPRANA EN NIÑOS CON PARÁLISIS CEREBRAL GMFCS $V$}

\author{
Patricio Pablo Manzone, ${ }^{1}$ María Selva Vallejos Arce, ${ }^{1}$ Eduardo Mariño Avalos, ${ }^{2}$ Maria Lorena Cardozo Iñiguez, ${ }^{3}$ José Gemetro ${ }^{4}$ \\ 1. Hospital Pediátrico “Dr. Avelino Castelán", Chaco, Argentina. \\ 2. Clínica Del Angelo, Formosa capital, Formosa, Argentina. \\ 3. Hospital de la Madre y el Niño, Formosa capital, Formosa, Argentina. \\ 4. Hospital 4 de Junio “Dr. Ramón Carrillo", Pcia. Roque Sáenz Peña, Chaco, Argentina.
}

\begin{abstract}
Objective: Spastic cerebral palsy $(\mathrm{SCP})$ is a cause of early onset scoliosis, although there are no data on its prevalence. Our objective was to determine the prevalence of early onset neuromuscular spinal deformities (SD) in severely compromised children with sCP. Methods: Cross-sectional quantitative, observational, exploratory, and descriptive study. Review of clinical records. Inclusion criteria: age 2 to 5 years, sCP, level V of the GMFCS, residents in our province. X-ray blind reading by 2 observers. The Student t test was used for parametric data and the chi-square test for non-parametric data. Level of statistical significance: $p<0.05$. Results: Thirty-eight cases of 158 registered were included. Average age: 3 years 7 months (2 years -5 years 2 months). Sex: 21 male/17 female. The predominant etiologies were perinatal: 21 (55.3\%), and the prevalent nutritional status was eutrophic: 28 cases (73.7\%). SD was very frequent: 32 patients (84.2\%) without statistical differences between sexes; there were 20 kyphoscoliosis, 1 lordoscoliosis, 6 scoliosis, 5 hyperkyphosis. Mean angular values: $23.9^{\circ}\left(10^{\circ}-50^{\circ}\right)$ for the frontal plane deformities and $58^{\circ}\left(9^{\circ}-92^{\circ}\right)$ for the sagittal deformities. Seventeen patients (44.7\%) had average pelvic obliquity of $15^{\circ}\left(2^{\circ}-30^{\circ}\right)$ without differences in patients with and without SD. There was no association between SD and etiology, digestive disorders, seizures, nutritional status, hip excentration, or limb deformities. Conclusions: The prevalence of SD in children up to 5 years old with severe SCP is high: $84.2 \%$ (32/38 cases). The orthopedic profile is children with sCP of any etiology at GMFCS level V, with multiple disabilities and independently of associated limb deformities. Level of evidence I; Diagnostic Studies - Investigating a Diagnostic Test: Testing of previously developed diagnostic criteria on consecutive patients (with universally applied reference "gold" standard).
\end{abstract}

Keywords: Scoliosis; Cerebral palsy; Spastin.

\section{RESUMO}

Objetivo: A Paralisia Cerebral espástica (PCe) é uma das causa de escoliose precoce,, embora não existam dados da prevalência. Nosso objetivo foi determinar a prevalência das deformidades espinhais (DE) neuromusculares de início precoce em crianças PCe severamente comprometidas. Métodos: Estudo quantitativo transversal, exploratório e descritivo, observacional. Revisão de prontuários. Critérios de inclusão: idade 2 a 5 anos, PCe, nível V do GMFCS, domiciliado na nossa província. Leitura cega das radiografias por 2 observadores. Foram utilizados o teste T de Student para dados paramétricos e, para o não-paramétricos, o chi-quadrado. Nível de significância estatística: $p<0.05$. Resultados: 38 casos de 158 achados foram incluídos. Idade média: 3 anos 7 meses (2 anos - 5 anos 2 meses). Sexo: 21 homens/17 mulheres. Predominaram as causas perinatais: 21 (55,3\%), e o estado nutricional prevalecente foi o eutrofico: 28 casos (73,7\%). A DN foi muito frequente: 32 casos (84,2\%), e nenhuma diferença estatística entre os sexos; houve 20 cifoescoliose, 6 escolioses, 1 lordoescoliose, 5 hipercifose. Valores médios angulares: $23.9^{\circ}\left(10^{\circ}-50^{\circ}\right)$ para as deformidades frontais e $58^{\circ}\left(9^{\circ}-92^{\circ}\right)$ para as sagitais. Dezessete casos (44,7\%) apresentavam obliquidade pélvica média de $15^{\circ}\left(2^{\circ}-30^{\circ}\right)$; não há diferenças em pacientes com e sem DE. Não havia nenhuma associação entre a DE e etiologia, distúrbios digestivos, convulsões, estado nutricional e luxação dos quadris ou deformidades dos membros. Conclusões: A prevalência de DE em crianças de até 5 anos com PCE severa é alta: $84.2 \%$ (32/38 casos). O perfil ortopédico são todas crianças GMFCS V, de qualquer etiologia, com diferentes deficiências e independentemente das deformidades dos membros associados. Nível de evidência I; Estudos diagnósticos - Investigação de um exame para diagnóstico. Teste de critérios diagnósticos desenvolvidos anteriormente em pacientes consecutivos (com padrão de referência "ouro" aplicado).

Descritores: Escoliose; Paralisia cerebral; Espastina

\section{RESUMEN}

Objetivo: Evaluar la influencia de la técnica MIS-TLIF sobre los parámetros espinopélvicos de pacientes sometidos a artrodesis lumbar. Objetivo: La parálisis cerebral espástica (PCe) es una causa de escoliosis de comienzo temprano, aunque no existen datos de su prevalencia. Nuestro objetivo fue determinar la prevalencia de las deformidades espinales (DE) neuromusculares de comienzo temprano en niños con PCe severamente comprometidos. Métodos: Estudio transversal cuantitativo, observacional, exploratorio y descriptivo. Revisión de historias clínicas. Criterios de inclusión: edad 2 a 5 años, PCe, nivel V del GMFCS, domiciliados en nuestra provincia. Lectura a ciegas

Study conducted at the Hospital Pediátrico "Dr. Avelino Castelán", Chaco, Argentina.

Correspondence: Dr. Patricio Manzone. Monteagudo 201, (3500) Resistencia, Chaco, Argentina. manzonepatricio@ hotmail.com 
de radiografías por 2 observadores. Se usó el test $t$ de Student para datos paramétricos y el chi-cuadrado para los no paramétricos. Nivel de significación estadística: $p$ < 0,05. Resultados: Treinta y ochos casos de 158 registrados fueron incluidos. Edad promedio: 3 años 7 meses (2 años - 5 años 2 meses). Sexo: 21 varones/17 mujeres. Las etiologías predominantes fueron perinatales: 21 (55,3\%), y el estado nutricional prevalente el eutrófico: 28 casos (73,7\%). La DE fue muy frecuente: 32 pacientes (84,2\%), sin diferencias estadísticas entre sexos; hubo 20 cifoescoliosis, 1 lordoescoliosis, 6 escoliosis, 5 hipercifosis. Valores angulares medios: $23,9^{\circ}\left(10^{\circ}\right.$ - 50 $0^{\circ}$ para las deformidades frontales y $58^{\circ}\left(9^{\circ}-92^{\circ}\right)$ para las sagitales. Diecisiete pacientes $(44,7 \%)$ presentaron oblicuidad pélvica promedio de $15^{\circ}\left(2^{\circ}-30^{\circ}\right)$, sin diferencias en pacientes con y sin DE. No hubo asociación entre DE y etiología, trastornos digestivos, convulsiones, estado nutricional, excentración de caderas ni deformidades de miembros. Conclusiones: La prevalencia de DE en niños de hasta 5 años con PCe severa es alta: $84,2 \%$ (32/38 casos). El perfil ortopédico es de niños con PCe V del GMFCS de cualquier etiología, con diversas discapacidades e independientemente de las deformidades asociadas de los miembros. Nivel de Evidencia I; Estudios de diagnósticos - Investigación de un examen para diagnóstico. Pruebas de criterios de diagnósticos desarrollados anteriormente en pacientes consecutivos (con estándar de referencia "oro" aplicado).

Descriptores: Escoliosis; Parálisis cerebral; Espastina.

\section{INTRODUCTION}

Neuromuscular spinal deformities appear in the child secondary to various conditions and cause a complex and progressive distortion of the trunk. On the other hand, early-onset scoliosis starts during the first few years of life, ${ }^{1-3}$ in infancy and early childhood, and may have multiple causes, among which neuromuscular diseases stand out. ${ }^{4}$ Cerebral palsy (CP) is one of these disorders, ${ }^{5}$ being epidemiologically significant since its global prevalence ranges from 1 to 7 per 1000 children, ${ }^{6}$ affecting approximately 2 out of every 1000 live births. ${ }^{7-11}$

A number of deformities may appear in the spine of the child with spastic $\mathrm{CP}$, but the most frequent is neuromuscular scoliosis (NS), ${ }^{12-15}$ especially in the thoracolumbar region. ${ }^{12,13,15}$ It is recognized that children with more profound and severe compromise are at higher risk for its occurrence, $5,12,14-18$ and it is not uncommon to have pelvic obliquity associated with the NS, which further aggravates the condition. ${ }^{5,12,13,15,16,18,19}$ These deformities increase as long as there is significant growth ahead such that the earlier it begins, the greater the potential to create a severe deformity by the end of that growth. Thus, the curves of the spastic CP that begin very early, and are not treated progress, and require much more costly treatments with higher morbidity and mortality, ${ }^{20}$ having a greater negative impact on the patient's quality of life. ${ }^{21}$

According to the literature, the spinal deformity of CP appears well into childhood, at around 6, 7, or 8 years of age, ${ }^{14,19}$ its appearance being very rare in young children. ${ }^{12}$ But in reality, there are no concrete data about the prevalence of the forms of early-onset spastic CP, and only its rarity is mentioned. ${ }^{12,18}$

This study sought to determine the prevalence of early-onset spinal deformity in patients between 2 and 5 years of age with severe spastic CP treated at a provincial pediatric hospital, as well as to describe the orthopedic clinical profile of children with this deformity, and to establish criteria for early detection.

\section{METHODS}

This non-experimental primary research had a quantitative, mixed exploratory and descriptive, observational, and cross-sectional design. ${ }^{22-24}$ We worked with the universe of children severely compromised by spastic CP treated through the State Public Health System $^{25}$ in our province during the years covered by the investigation - a total of 158 cases. We used non-probabilistic intentional sampling, ${ }^{26}$ with the following inclusion criteria: aged between 2 and 5 years with severe spastic CP at level $V$ of the Gross Motor Function Classification System (GMFCS), ${ }^{27}$ to have been treated in the Pediatric Orthopedics and Traumatology Service of the hospital (authorization by the Hospital Institutional Review Board: Methodological and Ethical Evaluation Memo of 27 November 2014), to have been born between 2009 and 2013, and living in the province. All the patients treated had an Informed Consent Form signed by their parents, guardians, or representatives, upon admission.

The sampling process was based on the review of clinical case histories during regular medical check-ups and on spinal radiographs. The variables studied were sex, age at the time of interview, residence address, etiology of the CP, type of spinal deformity, location of the deformity, side of the frontal curves, angle value, degree of pelvic obliquity, presence of convulsions, presence of digestive/ swallowing disorders, nutritional state, presence of tracheostomy, and associated orthopedic deformities of limbs.

In each case, frontal and lateral radiographs were taken in seated and lying positions to assess the existence of spinal deformity. Since these children had no trunk control, a special radiolucid support produced by the hospital itself according to that described by Miller ${ }^{12}$ was used. To ensure reproducibility of the data, a blind reading of the radiographs was performed by qualified doctors of the Orthopedics and Traumatology Service of the hospital, following the criteria of the SRS and other authors. ${ }^{28,29}$ Nutritional status was evaluated with the Krick theoretical weight table for quadriplegic children. ${ }^{30}$

The results were analyzed with descriptive statistics, ${ }^{31}$ through SPSS ${ }^{\circledR}$ software, using the Student's t-test for parametric and the chi square test for non-parametric data. ${ }^{23,31-33} \mathrm{P}<0.05$ was adopted as the level of statistical significance.

\section{RESULTS}

Of the universe of 158 registered cases, 39 met the inclusion criteria. However, one of them died shortly after the clinical evaluation without having completed the radiographical examination, so the results of a total of 38 patients comprising the corresponding sample were analyzed.

Sociodemographic data: The mean age was 3 years and 7 months (ranging from 2 years to 5 years and 4 months). The sample was made up of 21 males (55.3\%) and 17 females (44.7\%) and there were no statistical differences in age between the sexes $(p=0.696)$.

The two most populated provincial departments provided the highest number of total cases - 25 patients (65.8\%) - and the highest number of patients with deformities. They are also the ones with the most people with spastic quadriplegia censused in our province. ${ }^{34}$ When we compared the proportion of sample cases from these departments to those from the other departments and, likewise, the total number of spastic quadriplegics we found no statistical differences. Thus, we consider the sample to be representative. (Table 1)

When considering the socioeconomic conditions according to the percentage of households with unsatisfied basic needs (UBN), ${ }^{35,36}$

Table 1. Frequency distribution of the sample cases and the population (censused). Comparison between the sample and the censused population.

\begin{tabular}{c|c|c|c}
\hline Department of Origin & Sample & Census & ${ }^{*} \mathbf{p}$ \\
\hline Department 1 & $18(47.4 \%)$ & $133(49.1 \%)$ & 0.981 \\
\hline Department 2 & $7(18.4 \%)$ & $37(13.7 \%)$ & 0.589 \\
\hline Remaining locations & $13(34.2 \%)$ & $101(37.2 \%)$ & 0.852 \\
\hline Total & 38 & 271 & \\
\hline
\end{tabular}

No statistically significant differences were observed between the percentages of census and sample values. The goodness-of-fit test between the patient sample and census was not statistically significant $(p=0.543)$. 
the departments with the largest population, the greatest number of spastic quadriplegics, and the highest contribution of cases (27 of the 38 ) are those with less than $20 \%$ of households with UBN. ${ }^{37,38}$

Data dependent on the medical variables: The perinatal etiology of CP was prevalent. (Table 2) Twenty-six (68.4\%) patients had different types of associated epileptic seizures in treatment; 25 (65.8\%) had swallowing/digestive disorders (most of them (92\%) requiring a permanent nasogastric tube or gastrostomy), but only 2 underwent permanent tracheostomy. The prevalent nutritional state was eutrophic with 28 cases (73.7\%) with only 6 cases of undernourishment. (Figure 1) Data related to deformity: Spinal deformity was very common in this group: 32 patients (84.2\%) had some form, the most frequently observed being the combination of frontal (scoliotic) and sagittal curves (Figure 2 and 3).

The predominant location of the deformity in the 32 children who had it was the thoracolumbar region. (Figure 4) Of the 27 frontal curves, 14 (51.9\%) were on the right side and 13 (48.1\%) were on the left. The mean angle of the frontal deformities (27 curves) was $23.9^{\circ}$ and of the sagittal deformities (26 curves) was $58^{\circ}$. (Table 3)

No statistical differences were observed between the sexes for patients with and without deformity $(p=0.778)$. Considering sex with respect to the type of deformity, although there was a slight predominance of kyphoscoliosis in females and hyperkyphosis in males, there were no significant differences ( $p=0.205)$. (Table 4)

As we have seen, $55.3 \%$ (21/38) of the patients had perinatal $\mathrm{CP}$ and this ratio was maintained in the 32 patients with deformity $(53.1 \%, 17 / 32)$. Even though perinatal causes were much more frequent, there was no significant association between it and the presence of deformity $(p=0.540)$. (Table 5$)$

The existence or not of deformity was not associated with digestive disorders $(p=0.323)$, convulsions ( $p=0.391)$, or any nutritional state $(p=0.335)$.

Finally, when the subclassification of GMFCS V ${ }^{39}$ into subgroups of progressively higher and increasing probabilities of postoperative complications according to the number of multiple disabilities is considered, only 2 of our 32 patients with spinal deformity underwent tracheostomy, although 23 had gastrostomies and permanent nasogastric tubes. Thus, 17 patients with deformity were of subtype 5.3 (i.e., those with the highest range of multiple disabilities and with a higher rate of complications in deformity surgeries). (Table 6)

Table 2. Frequency distribution and percentage of the etiology of the $\mathrm{CP}$.

\begin{tabular}{c|c|c}
\hline Etiology of the CP & Number of cases & Percentage \\
\hline Perinatal & 21 & $55.3 \%$ \\
\hline Congenital & 10 & $26.3 \%$ \\
\hline Postnatal & 6 & $15.8 \%$ \\
\hline Mixed & 1 & $2.6 \%$ \\
\hline Total & 38 & 100.0 \\
\hline
\end{tabular}

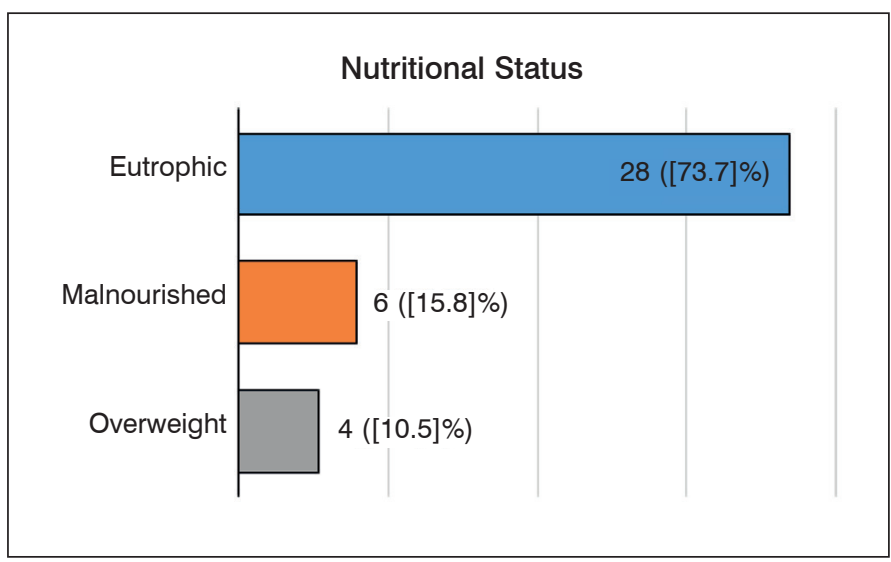

Figure 1. Percent distribution of patient nutritional status.

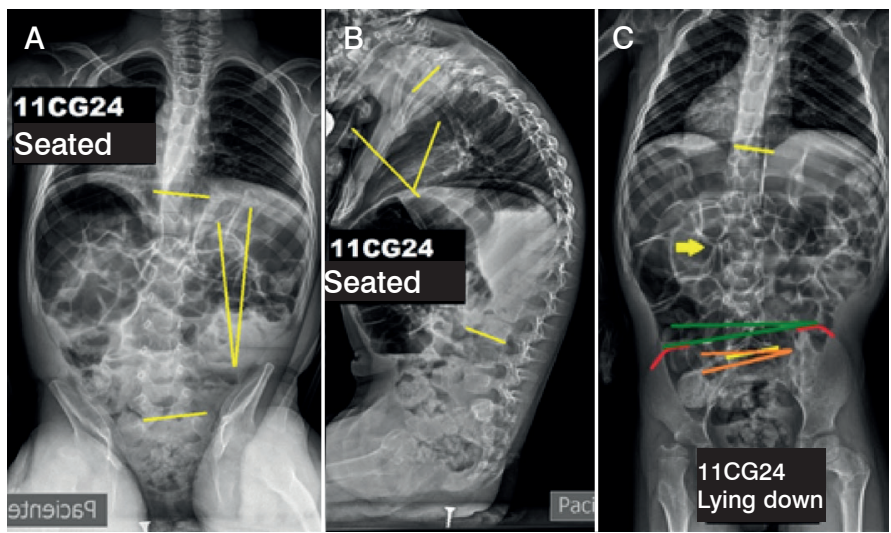

Figure 2. Patient aged 4 years 1 month. Seated radiographs (A and B): Scoliosis $20^{\circ}$, Kyphosis $69^{\circ}$. The pelvic obliquity associated with the thoracolumbar scoliosis is observed in the radiograph in the lying down position (C).

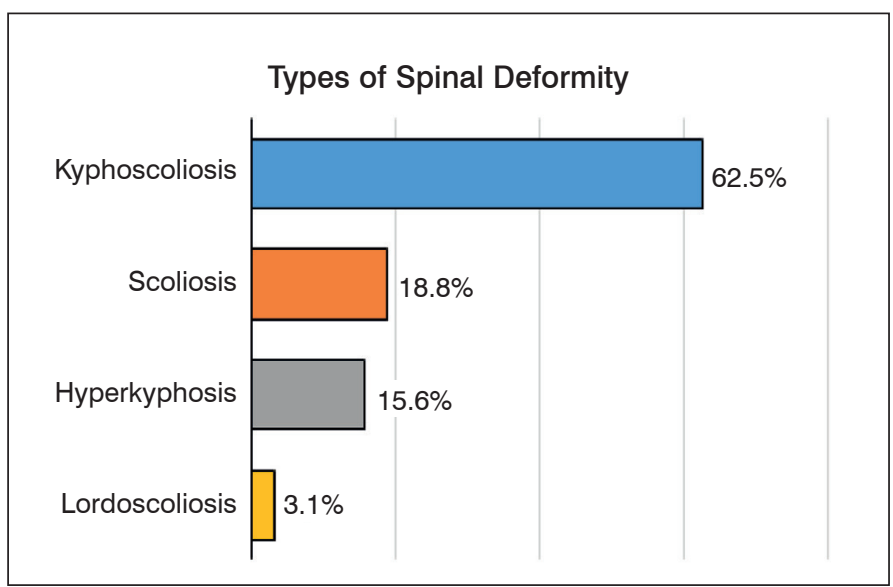

Figure 3. Percent distribution of types of spinal deformity.

\section{Location of the spinal deformity}

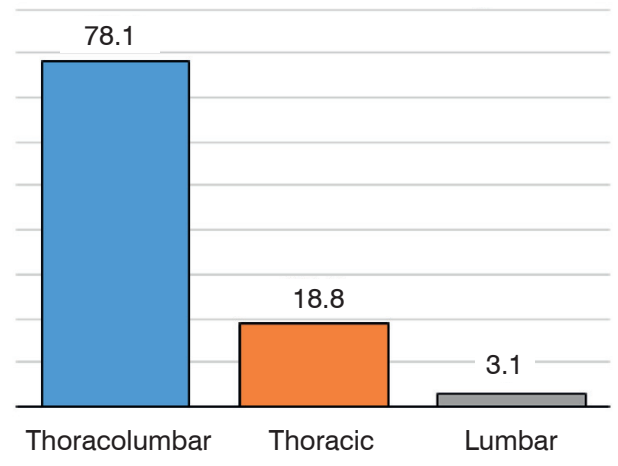

Figure 4. Percent distribution of the location of the spinal deformity.

Table 3. Frontal and sagittal curve angle values

\begin{tabular}{c|c|c|c|c|c|c|c}
\hline Variable & $\mathbf{N}$ & Mean & Median & Mode & $\begin{array}{c}\text { Standard } \\
\text { Deviation }\end{array}$ & Minimum & Maximum \\
\hline $\begin{array}{c}\text { Angle } \\
\text { Value }\end{array}$ & & & & & & \\
\hline $\begin{array}{c}\text { Frontal } \\
\text { angle }\end{array}$ & 27 & 23.9 & 20.0 & 20,0 & 11,77 & 10 & 50 \\
\hline $\begin{array}{c}\text { Sagittal } \\
\text { angle }\end{array}$ & 26 & 58.0 & 55.0 & 55.0 & 16.73 & 9 & 92 \\
\hline
\end{tabular}


Table 4. Frequency distribution and percentage of type of deformity by sex.

\begin{tabular}{c|c|c|c|c}
\hline \multicolumn{2}{c|}{$\begin{array}{c}\text { Spinal deformity } \\
\text { Male }\end{array}$} & \multicolumn{2}{c|}{ Sex } & \multirow{2}{*}{ Total } \\
\cline { 2 - 4 } Scoliosis & Frequency & 5 & 1 & 6 \\
\cline { 2 - 5 } & $\%$ & $23.8 \%$ & $5.9 \%$ & $15.8 \%$ \\
\hline \multirow{2}{*}{ Kyphoscoliosis } & Frequency & 8 & 12 & 20 \\
\cline { 2 - 5 } & $\%$ & $38.1 \%$ & $70.6 \%$ & $52.6 \%$ \\
\hline \multirow{2}{*}{ Lordoscoliosis } & Frequency & 1 & 0 & 1 \\
\cline { 2 - 5 } & $\%$ & $4.8 \%$ & $0.0 \%$ & $2.6 \%$ \\
\hline \multirow{2}{*}{ Hyperkyphosis } & Frequency & 4 & 1 & 5 \\
\cline { 2 - 5 } & $\%$ & $19.0 \%$ & $5.9 \%$ & $13.2 \%$ \\
\hline \multirow{2}{*}{ None } & Frequency & 3 & 3 & 6 \\
\cline { 2 - 4 } & $\%$ & $14.3 \%$ & $17.6 \%$ & $15.8 \%$ \\
\hline \multirow{2}{*}{ Total } & Frequency & 21 & 17 & 38 \\
\cline { 2 - 4 } & $\%$ & $100.0 \%$ & $100.0 \%$ & $100.0 \%$ \\
\hline
\end{tabular}

Table 5. Type of deformity frequency distribution and percentages by etiology of the CP.

\begin{tabular}{c|c|c|c|c|c|c}
\hline \multirow{2}{*}{$\begin{array}{c}\text { Spinal Deformity } \\
\text { Congenital }\end{array}$} & \multicolumn{4}{|c|}{ Etiology of the CP } & \multirow{2}{*}{ Total } \\
\cline { 2 - 7 } $\begin{array}{c}\text { Without } \\
\text { deformity }\end{array}$ & Prequency & 2 & 4 & 0 & 0 & 6 \\
\cline { 2 - 7 } & $\%$ & $33.3 \%$ & $66.7 \%$ & $0.0 \%$ & $0.0 \%$ & $100.0 \%$ \\
\hline \multirow{2}{*}{ Scoliosis } & Frequency & 1 & 4 & 1 & 0 & 6 \\
\cline { 2 - 7 } & $\%$ & $16.7 \%$ & $66.7 \%$ & $16.7 \%$ & $0.0 \%$ & $100.0 \%$ \\
\hline \multirow{2}{*}{ Kyphoscoliosis } & Frequency & 6 & 9 & 4 & 1 & 20 \\
\cline { 2 - 7 } & $\%$ & $30.0 \%$ & $45.0 \%$ & $20.0 \%$ & $5.0 \%$ & $100.0 \%$ \\
\hline \multirow{2}{*}{ Lordoscoliosis } & Frequency & 1 & 0 & 0 & 0 & 1 \\
\cline { 2 - 7 } & $\%$ & $100.0 \%$ & $0.0 \%$ & $0.0 \%$ & $0.0 \%$ & $100.0 \%$ \\
\hline \multirow{2}{*}{ Hyperkyphosis } & Frequency & 0 & 4 & 1 & 0 & 5 \\
\cline { 2 - 7 } & $\%$ & $0.0 \%$ & $80.0 \%$ & $20.0 \%$ & $0.0 \%$ & $100.0 \%$ \\
\hline \multirow{2}{*}{ Total } & Frequency & 10 & 21 & 6 & 1 & 38 \\
\cline { 2 - 7 } & $\%$ & $26.3 \%$ & $55.3 \%$ & $15.8 \%$ & $2.6 \%$ & $100.0 \%$ \\
\hline
\end{tabular}

Table 6. GMFCS V multiple disability sub-classification by the existence or non-existence of deformity.

\begin{tabular}{c|c|c}
\hline \multirow{2}{*}{ GMFCS V sub-classification } & With Deformity & Without Deformity \\
\cline { 2 - 3 } & Frequency (\%) & Frequency (\%) \\
\hline Total & $32(100.0)$ & $6(100.0)$ \\
\hline Subgroup 1 & $9(28.1)$ & $1(16.7)$ \\
\hline Subgroup 2 & $6(18.8)$ & $1(16.7)$ \\
\hline Subgroup 3 & $17(53.1)$ & $4(66.6)$ \\
\hline
\end{tabular}

However, no significant differences were found between the patients with and without deformity in the different subgroups $(p=0.197)$ nor were there any in the patients with distinct deformities between the different subgroups ( $p=0.197$ ).

Data related to pelvic obliquity: Seventeen (44.7\%) of the 38 patients presented pelvic obliquity: 16 with spinal deformity and one without deformity. The mean pelvic obliquity was $15^{\circ}$ (range $2^{\circ}-30^{\circ}$ ). The presence of obliquity in patients with and without spinal deformity did not show a statistical difference $(p=0.131)$. Furthermore, the various deformities were distributed evenly between the cases with and without pelvic obliquity.

When we evaluated the relationship between cases with and without spinal deformity, presence of pelvic obliquity, and association with hip excentration, there were no statistical differences $(p=0.132)$ between these factors in the contingency tables (Table 7 and Figure 5). Hip adduction, subluxation, and luxation are distinct moments and modalities of "hip excentration", 12,15,40,41 so we decided to combine them all under the latter term for the purposes of statistical analysis. Interestingly, all the patients without hip excentration (12) had spinal deformity whether or not they had associated pelvic obliquity.
Table 7. Frequency distribution and percentage of pelvic obliquity by the existence or not of spinal deformity and excentration of the hips.

\begin{tabular}{|c|c|c|c|c|c|c|}
\hline \multirow{2}{*}{\multicolumn{4}{|c|}{ Excentration of the hips }} & \multicolumn{2}{|c|}{ Spinal Deformity } & \multirow{3}{*}{$\begin{array}{c}\text { Total } \\
12 \\
\end{array}$} \\
\hline & & & & Yes & No & \\
\hline \multirow{6}{*}{ Yes } & \multirow{4}{*}{$\begin{array}{l}\text { Pelvic } \\
\text { Obliquity }\end{array}$} & \multirow{2}{*}{ Yes } & Frequency & 11 & 1 & \\
\hline & & & $\%$ & $91.67 \%$ & $8.33 \%$ & $100,00 \%$ \\
\hline & & \multirow{2}{*}{ No } & Frequency & 9 & 5 & 14 \\
\hline & & & $\%$ & $64.29 \%$ & $35.71 \%$ & $100,00 \%$ \\
\hline & \multirow{2}{*}{\multicolumn{2}{|c|}{$\begin{array}{c}\text { Total } \\
\%\end{array}$}} & Frequency & 20 & 6 & 26 \\
\hline & & & $76.92 \%$ & $23.08 \%$ & $100.00 \%$ & \\
\hline \multirow{6}{*}{ No } & \multirow{4}{*}{$\begin{array}{l}\text { Pelvic } \\
\text { Obliquity }\end{array}$} & \multirow{2}{*}{ Yes } & Frequency & 5 & 0 & 5 \\
\hline & & & $\%$ & $100.00 \%$ & $0.00 \%$ & $100.00 \%$ \\
\hline & & \multirow{2}{*}{ No } & Frequency & 7 & 0 & 7 \\
\hline & & & $\%$ & $100.00 \%$ & $0.00 \%$ & $100.00 \%$ \\
\hline & \multirow{2}{*}{\multicolumn{2}{|c|}{$\begin{array}{c}\text { Total } \\
\%\end{array}$}} & Frequency & 12 & 0 & 12 \\
\hline & & & $100.00 \%$ & $0.00 \%$ & $100.00 \%$ & \\
\hline \multirow{6}{*}{ Total } & \multirow{4}{*}{$\begin{array}{l}\text { Pelvic } \\
\text { Obliquity }\end{array}$} & \multirow{2}{*}{$\mathrm{Si}$} & Frequency & 16 & 1 & 17 \\
\hline & & & $\%$ & $94.12 \%$ & $5.88 \%$ & $100.00 \%$ \\
\hline & & \multirow{2}{*}{ No } & Frequency & 16 & 5 & 21 \\
\hline & & & $\%$ & $76.19 \%$ & $23.81 \%$ & $100.00 \%$ \\
\hline & \multirow{2}{*}{\multicolumn{2}{|c|}{$\begin{array}{c}\text { Total } \\
\%\end{array}$}} & Frequency & 32 & 6 & 38 \\
\hline & & & $84.21 \%$ & $15.79 \%$ & $100.00 \%$ & \\
\hline
\end{tabular}

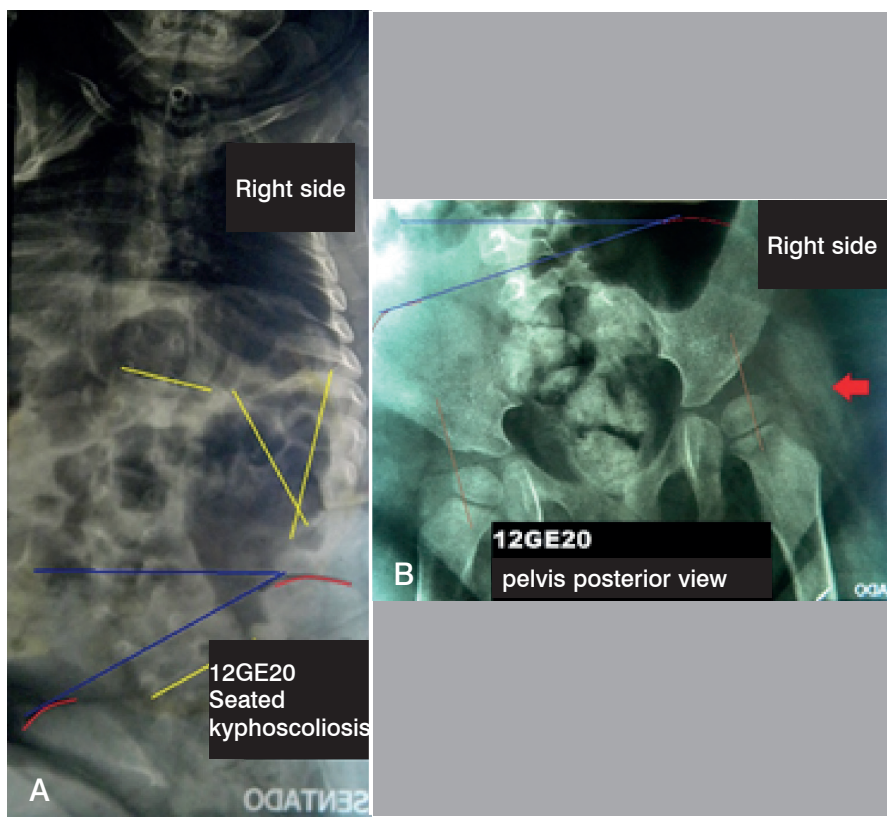

Figure 5. Patient aged 2 years 2 months. Radiographs of the front of the spine in the seated position (A) and of the posterior-anterior pelvis (B). In the spinal radiograph, the measurement of pelvic obliquity is observed and, in the posterior-anterior radiograph, its direction, and the excentration of the right hip.

Data related to associated orthopedic deformities: Finally, there were orthopedic deformities of the associated limbs in all cases except one (1). The most common deformities (those observed in more than 10 patients) were assessed statistically in search of some association with the presence or not of spinal deformity, but showed no significant association.

\section{DISCUSSION}

The term CP is a "diagnostic umbrella" that comprises a group of pathologies of different etiologies, which must strictly comply with the inclusion criteria for the disease. ${ }^{42}$ The wide range of entities that comprise it, the lack of a unanimous consensus to make the diagnosis, together with the fact that diagnosis is very difficult prior 
to one year or many times prior to two years of age, often causes the subregistration of records of children with $\mathrm{CP}^{8,12,43}$

In our province there is no integrated registration of the number of children with spastic quadriplegic $\mathrm{CP}$, but cross-linking the data from different official departments for the year $2015,25,34,44519$ patients with spastic CP were reported in the province, all ages and topographies included, and 334 patients with spastic quadriplegia, all ages and etiologies (among them CP) included. Therefore, the universe of 158 children (patients under 14 years of age, as defined by the Provincial Public Health System) with spastic CP who received assistance in our hospital (the only pediatric center in the province) ${ }^{25}$ is not very far from reality.

If we look at the distribution of the population across the provincial departments, the frequency of cases in the sample aligns with it. ${ }^{38,45}$ Additionally, the ratios of censused cases from the departments with higher demographic density to their total number of spastic quadriplegics did not show statistical differences.

According to the literature, CP spinal deformity appears well into childhood, at around 7 or 8 years of age ${ }^{14}$ and is very rare in young children. ${ }^{12}$ Patel and Shapiro ${ }^{46}$ state that deformity develops early (2 to 5 years) but do not offer any bibliographical or statistical proof of cases, they do not establish the age of the first controls, and they only cite one example of a three-year-old and another of a seven-year-old in their article. Also, Gu et al. ${ }^{47}$ found that age is the most important predictive factor for the development and progression of deformity. However, they set the cutoff age for progression of Cobb angles greater than $40^{\circ}$ at 12 years and did not establish the youngest age of onset.

For this study, we chose 2 years as the starting point because the formal spastic condition is usually defined around 2 years of age. ${ }^{43}$ Also, after 2 years of age, the classification system for the degree of compromise (GMFCS) offers adequate stability in successive evaluations. ${ }^{48}$

Furthermore, it is known that the development and the prevalence of this deformity are proportional to the degree of neurological compromise and inversely proportional to walking ability. ${ }^{49}$ Thus, the criterion for selection of the most affected (CMFCS V) children is in direct relation to the high frequency in our cases.

Here, there were no statistical differences between the boys and the girls in terms of the presence of deformity $(p=0.777)$, both sexes having been affected in a comparable manner.

\section{Frequencies and relationships with the provenance of the cases}

In our 38 patients, averaging 3 years and 7 months in age, we found a high frequency of spinal deformity (32 patients $=84.2 \%$ ). As we have seen, the 32 patients with deformities were distributed among the different provincial departments in accordance with the distribution of the general population and of spastic quadriplegics.

It is generally recognized that $\mathrm{CP}$ is more prevalent in the most disadvantaged socio-economic groups, ${ }^{7}$ but in the current investigation, we found no relationship between greater socio-economic difficulties and a higher proportion of cases with deformities. In fact, taking the proportion of UBN households by department into account, our province had an average of $23.2 \%$ of its households with UBN. ${ }^{38}$ But in this study, the departments with the higher proportion of households with UBN (above 20\%) accounted for only 10 of the analysis subjects (7 with deformities). Also, using the Gini coefficient ${ }^{50,51}$ to measure socio-economic inequality among the different sanitary regions of the province, no significant differences in the frequency of cases with and without deformities were observed. Thus, those regions with a Gini coefficient greater than 0.4 (the alarm threshold for socio-economic inequality) are those that showed the lowest proportion of patients and of cases with deformity with respect to the spastic quadriplegics censused.*

In summary, it can be established that the prevalence of spinal

\footnotetext{
The Gini coefficient is represented by a number between 0 and 1, in which 0 corresponds to perfect equality (all have the same income) and 1 corresponds to perfect inequality (one person has all the income and the others none). ${ }^{45}$
}

deformity in young severely affected spastic children is very high $(84.2 \%)$, that the distribution of its frequency is aligned with demographic population density variables, and that the different socio-economic variables of the departments do not influence it.

\section{Factors associated with the presence of deformity}

There is controversy around the appearance and development of scoliosis in CP, given that there is no solid evidence in the literature, ${ }^{52}$ no certain association having been found with defined risk factors. ${ }^{53}$

The incidence of CP is correlated both with gestational age and low birth weight, ${ }^{11,15,54-56}$ these being the most important recognizable factors among perinatal causes. However, as we have seen, there was no significant statistical relationship in our patients that would establish a higher frequency of spinal deformity or specific etiological type of spastic CP. (Table 5)

We also could not confirm any association between early development of a spinal deformity and the existence of digestive disorders, convulsions, or any particular nutritional state of the patients.

Jain et al. ${ }^{39}$ sub-classified patients with GMFCS V CP into progressive subgroups of risk of the probability of complications in spinal deformity surgeries by number of disabilities presented. Their article demonstrates that the group of cases selected for our study includes a subgroup of patients at high risk for presenting postoperative complications of advanced deformities at later ages. However, not finding significant differences in the subgroups between patients with and without deformity, or between the different types of deformities, (Table 6) it can be established that all the GMFCS $V$ spastic $\mathrm{CP}$ children, regardless of subgroup, are at high risk of early-onset spinal deformity.

As regards the presence of orthopedic deformities of the limbs, we have seen that there were no significant differences between each of them and the presence or not of spinal deformities. Consequently, it can be considered that the existence of any deformities of the limbs does not constitute per se a red flag for the early appearance of spinal deformity.

An important point is the relationship between spinal deformity and pelvic obliquity, and between both of these and hip excentration. The work of Patel and Shapiro ${ }^{46}$ in this area does not allow valid conclusions since it was not homogeneous: it combined different neuromuscular conditions and included only 26 spastic quadriplegic CP patients, moreover, a mix of GMFCS IV and V levels. In our series, which was homogeneous, consisting of young GMFCS $V$ children (2 to 5 years of age), we did not find significant differences in relation to pelvic obliquity between patients with and without spinal deformity, nor were there statistical differences ( $p=0.132$ ) between cases with and without deformity, the existence or not of pelvic obliquity, and association or not with hip excentration. (Table 7) Therefore, in this group of young children, pelvic obliquity does not seem to act as it does in older children as a "marker of the appearance of scoliosis", 57 and, in agreement with that established by Loeters et al. in older children, ${ }^{53}$ it also shows that the evidence of any association between scoliosis, pelvic obliquity, and hip luxation at this young age is very weak.

Although there are controversial findings about the association between the direction of scoliosis and the direction of pelvic obliquity and/or the "windswept" hip deformity ${ }^{58-60}$ in children above 6 years of age, in this series the laterality of the scoliosis did not seem to influence excentration. (Figures 5 and 6)

\section{Establishing a profile of the patient at risk}

It can be established then that a young child (2 to 5 years of age) severely compromised (quadriplegic with total body involvement) with GMFCS $\vee$ spastic CP has a high probability of presenting a neuromuscular spinal deformity regardless of the socio-economic status of place where the patient comes from.

The most common deformity is kyphoscoliosis, followed by scoliosis and the most common location is the thoracolumbar spine. However, it does not present a systematically associated pelvic obliquity.

This deformity appears in any etiology of the CP. The children at 


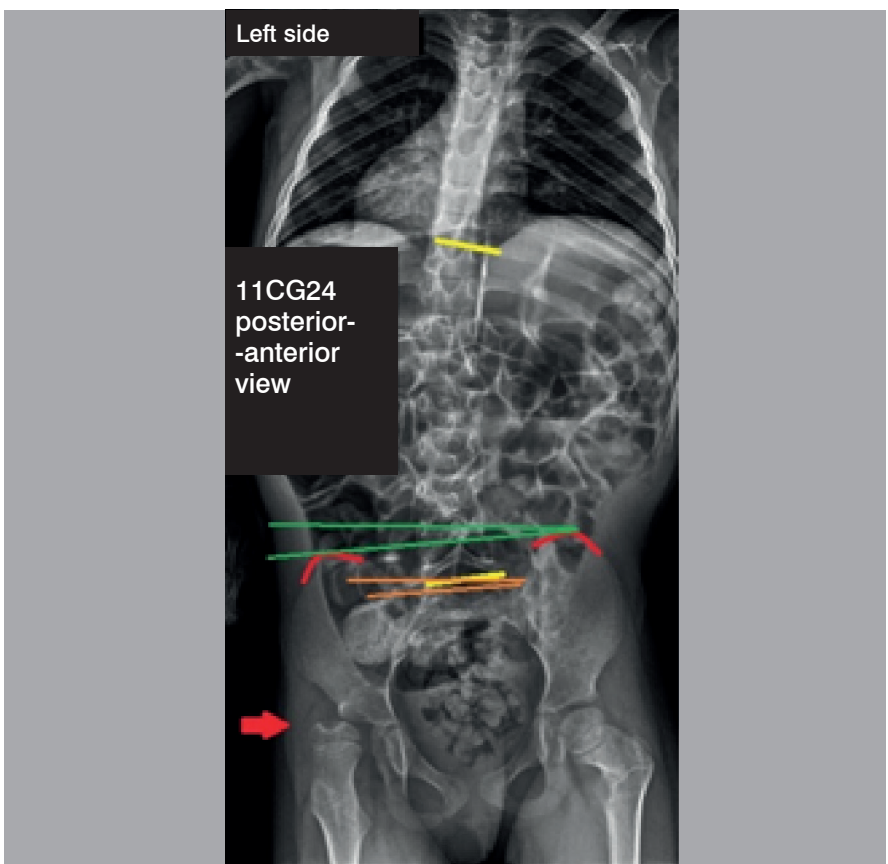

Figure 6. Case aged 4 years 1 month. Scoliosis $20^{\circ}$, Kyphosis $69^{\circ}$ (not visible in this figure). In this panoramic radiograph, the measurement of pelvic obliquity, its direction, and the excentration of the left hip are observed. risk did not show any apparent statistical association with any limb deformity; even though it seems to be more frequent in those without hip excentration, no statistically association was found.

\section{CONCLUSIONS}

The prevalence of neuromuscular spinal deformities in young children with severe spastic CP (GMFCS V) is high and the age of onset is much earlier than that suggested by the literature.

The proportion of cases aligns with demographic distribution, no matter the socio-economic status of the place.

Children from 2 to 5 years of age severely compromised by spastic CP with a high frequency of the appearance of neuromuscular spinal deformity are all GMFCS V, of any CP etiology, with varying degrees of multiple disabilities, regardless of whatever orthopedic limb deformities may exist.

The detection of early spinal deformities should focus on all these children.

\section{ACKNOWLEDGEMENTS}

The authors would like to acknowledge Professors Helton Defino and Alfredo Zurita for their assistance, advice, and help in conducting the investigation.

All authors declare no potential conflict of interest related to this article.

CONTRIBUTION OF THE AUTHORS: Each author made significant individual contributions to this manuscript. PPM (0000-0002-3987-267X)*, MSVA(0000-0002-8621-0257)*, EMA(0000-0001-5454-9822)*, MLCI(0000-0003-4133-750X)*, and JG (0000-0003-3546-6022)* participated actively in the discussion of the results, the review, and the approval of the final version of the study. ${ }^{*}$ ORCID (Open Researcher and Contributor ID).

\section{REFERENCES}

1. Dickson R. Chapter 18. Early-onset Idiopathic scoliosis. In: Weinstein S, Editors. The Pediatric Spine: Principles and Practice. New York: Raven Press; 1994. p. 421-9.

2. Gillingham BL, Fan RA, Akbarnia BA. Early onset idiopathic scoliosis. J Am Acad Orthop Surg. 2016; 14(2):101-12.

3. Akbarnia BA. Management themes in early onset scoliosis. J Bone Joint Surg. 2007; 89 Suppl 1:42-54

4. Williams BA, Matsumoto $H$, McCalla DJ, Akbarnia BA, Blakemore LC, Betz RR, et al. Development and Initial Validation of the Classification of Early-Onset Scoliosis (C-EOS). J Bone Joint Surg Am. 2014; 96(16):1359-67.

5. Newton PO, Jarley ES, Yassay B, Wenger DR, Mubarak SJ. Chapter 24: Neuromuscular Scoliosis. In: Herkowitz HN, Garfin SR, Eismont FJ, Bell GR, Balderston RA, Editors. Rothman-Simeone The Spine. Philadelphia: Elsevier Saunders; 2011. p. 402-36.

6. Renshaw T. Cerebral Palsy. In: Morrisy RT, Weinstein SL, Editors. Lowell and Winter's Pediatric Orthopaedics. Philadelphia: Lippincott Williams \& Wilkins; 2001. p. 563-99.

7. Odding E, Roebroeck ME, Stam HJ. The epidemiology of cerebral palsy: Incidence, impairments and risk factors. Disabil Rehabil. 2006: 28(4):183-91.

8. Westbom L, Hagglund G, Nordmark E. Cerebral palsy in a total population of 4-11 year olds in southern Sweden. Prevalence and distribution according to different CP classification systems. BMC pediatr. 2007: 7:41.

9. Kruse M, Michelsen SI, Flachs EM, Brønnum-Hansen H, Madsen M, Uldall P. Lifetime costs of cerebral palsy. Dev Med Child Neurol. 2009; 51(8):622-8.

10. Park MS, Kim SJ, Chung CY, Kwon DG, Choi IH, Lee KM. Prevalence and lifetime healthcare cost of cerebral palsy in South Korea. Health Policy. 2011; 100(2-3):234-8.

11. Nelson KB, Blair E. Prenatal Factors in Singletons with Cerebral Palsy Born at or nearTerm. N Engl J Med. 2015; 373:946-53.

12. Miller F. Cerebral Palsy. New York: Springer-Verlag; 2005.

13. Herring JA. Tachdjian's Pediatric Orthopaedics. Philadelphia:WB Saunders Company; 2002.

14. Persson-Bunke M, Hagglund G, Lauge-Pedersen H, Wagner P, Westbon L. Scoliosis in a total population of children with Cerebral Palsy. Spine (Phila Pa 1976). 2012; 37(12):708-13.

15. Karol LA. Chapter 35 Disorders of the Brain. In: Herring JA. Tachdjian's Pediatric Orthopaedics. Philadelphia: Elsevier Saunders; 2014.

16. Bleck EE. Orthopaedic Management in Cerebral Palsy. Clinics in Developmental Medicine. Philadelphia: Lippincott Co; 1987.

17. Saito N, Ebara S, Ohotsuka K, Kumeta H, Takaoka K. Natural history of scoliosis in spastic cerebral palsy. Lancet. 1998; 351 (9117):1687-92.

18. Shah SA. Chapter 19: Treatment of Spinal Deformity in CP. In: BA Akbarnia BA, Yazici M, Thompson GH, editors. The Growing Spine. Berlim: Springer-Verlag; 2011. p. 229-39.

19. Bernadó MTJ, García ARE, Varea JIL, Pérez PR, Casanova YB, Marco JLG. Escoliosis en el paralítico cerebral gravemente afectado. Rehabilitación. 2004; 38(5):241-5.

20. Sitoula P, Holmes Jr L, Sees J, Rogers K, Dabney K, Miller F. The long-term outcome of early spine fusion for scoliosis in children with cerebral palsy. Clin Spine Surg. 2016; 29(8):E406-12.
21. Fernandes P, Weinstein SL. Natural history of early onset scoliosis. J Bone Joint Surgery. 2007; 89(suppl 1):21-33

22. Sabino C. Capítulo 6: El Diseño de Investigación. In: Carlos Sabino. El Proceso de Investigación Científica. Bogotá: Ed. Panamericana; 1992, p. 75-95.

23. Centers for Disease Control and Prevention: Principles of Epidemiology in Public Health Practice; 2012. Atlanta - Georgia. http://www.cdc.gov/ophss/csels/dsepd/SS1978/ SS1978.pdf

24. Bonita R, Beaglehole R, Kjellstrõm T. Capítulo 3: Tipos de Estudios. In: Bonita R, Beaglehole R, Kjellström T, editores. Epidemiología Básica. Washington, DC: OPS; 2008. p. 49-80.

25. Departamento de Estadística Sanitaria: Informe Estadístico de: Egresos hospitalarios en la Provincia con diagnósticos de Parálisis Cerebral y/o Encefalopatía, de los nacidos entre 2009 y 2013. 2014, Dirección de Unidad de Planificación Sectorial; Ministerio de Salud Pública de la Provincia. Comunicación Personal.

26. Sabino C. Capítulo 7: El Muestreo. In: Carlos Sabino. El Proceso de Investigación Científica. Bogotá; Ed. Panamericana; 1992. p. 97-106.

27. Palisano RJ, Rosenbaum P, Walter S, Russell D, Wood E, Galuppi B. Development and validation of a gross motor function classification system for children with cerebral palsy. Dev Med Child Neurol. 1997; 39(4):214-23.

28. Scoliosis Research Society (SRS): Scoliosis Research Society (SRS): SRS Terminology Committee and Working Group on Spinal Classification Revised Glossary of Terms; 2000. http://www.srs.org/professionals/glossary/SRS_revised_glossary_of_terms.htm.

29. O'Brien MF, Kuklo TR, Blanke KM, Lenke LG. Spinal Deformity Study Group: Radiographic Measurement Manual; 2008. Medtronic Sofamor Danek USA, Inc; http://www.oref.org/ docs/default-source/default-document-library/sdsg-radiographic-measuremntmanual.pdf?sfvrsn=2.

30. Krick J, Murphy-Miller P, Zeger S, Weight E. Pattern of Growth in Children with Cerebral Palsy. J Am Diet Assoc. 1996;96(7):680-5

31. Williams OD. Capítulo 4: Bioestadística básica: conceptos y métodos. In: Bonita R, Beaglehole R, Kjellström T, editores. Epidemiología básica. Washington, DC: OPS; 2008. p. 81-106.

32. Sabino C. Capítulo 10: El Procesamiento de los Datos. In: Carlos Sabino. El Proceso de Investigación Científica. Bogotá: Ed. Panamericana; 1992. p. 136-49.

33. Guyatt G, Haynes B, Sackett D. Chapter 15: Analyzing Data. In: Haynes RB, Sackett DL, Guyatt GH, P Tugwell P, editors. Clinical Epidemiology. How to do clinical practice research. Philadelphia: Lippincott Williams \&Wilkins, 2006. p. 446-60.

34. IProDiCh (Instituto Provincial para la Inclusión de las Personas con Discapacidad de la Provincia del Chaco): Registro Único de Personas con Discapacidad según el Certificado Único de Discapacidad (CUD). 2016; Comunicación Personal.

35. Feres JC, Mancero X. El método de las necesidades básicas insatisfechas (NBI) y sus aplicaciones en América Latina. Santiago de Chile, CEPAL, 2001. p. 7-8.

36. Bautista OF. La medida de necesidades básicas insatisfechas (NBI) como instrumento de medición de la pobreza y focalización de programas. Bogotá, CEPAL, 2007. p. 14-27. 
37. Instituto Nacional de Estadística y Censos (INDEC): Censo Nacional de Población, Hogares y Viviendas 2010: Censo del Bicentenario Resultados definitivos, Serie B N² 2. Tomo 1 y 2 . INDEC, Buenos Aires, octubre de 2012

38. Dirección Nacional de Relaciones Económicas con las Provincias (DINREP): Necesidades Básicas Insatisfechas (NBI). Información censal del año 2010 (Versión ampliada con datos departamentales). Enero 2014. http://www2.mecon.gov.ar/hacienda/dinrep/Informes/archivos/NBIAmpliado.pdf.

39. Jain A, Sponseller PD, Shah SA, Samdani A, Cahill PJ, Yaszay B, et al: Subclassification of GMFCS Level 5 Cerebral Palsy as a Predictor of Complications and Health-Related Quality of Life After Spinal Arthrodesis. J. Bone Joint Sur Am. 2016; 98(21):1821-8

40. Reimers J. The Stability of the Hip in Children: A Radiological Study of the Results of Muscle Surgery in Cerebral Palsy. Acta Orthop Scand Suppl. 1980; 184:1-100

41. Reimers J, Bleck E. Spastic paralytic dislocation of the hip. Dev Med Child Neurol. 1985; 27(3):401-3.

42. Badawi N, Watson L, Petterson B, Blair E, Slee J, Haan E, et al. What constitutes cerebra palsy? Dev Med Child Neurol. 1998; 40(8):520-7.

43. Tavera AR, Villanueva JAM, Saldaña MEA, Núñez AO, Labanino CV, Cruz SP, et al. La Clínica Conjunta y Permanente de Parálisis Cerebral Infantil Espástica entre los Servicios de Ortopedia Pediátrica, de Rehabilitación y de Comunicación Humana del Instituto Nacional de Rehabilitación. Acta Ortopédica Mexicana. 2006; 20(4):145-9.

44. Departamento de Estadística Sanitaria: Informe Estadístico: Datos de Morbilidad en la Provincia del Chaco según egresos hospitalarios del año 2015 con diagnóstico de Parálisis Cerebral; 2016. Dirección de Unidad de Planificación Sectorial; Ministerio de Salud Pública de la Provincia del Chaco. Comunicación Personal.

45. Vucko M, Oviedo E. Pequeños Titulares de Derechos. Análisis de la situación social de los niños, niñas y adolescentes de la Provincia. Documento final; Escuela de Gobierno, septiembre 2015, p. 4.

46. Patel J, Shapiro F. Simultaneous progression patterns of scoliosis, pelvic obliquity, and hip subluxation/dislocation in nonambulatory neuromuscular patients: an approach to deformity documentation. J Child Orthop. 2016; 9(5):345-56.

47. Gu Y, Shelton JE, Ketchum JM, Cifu DX, Palmer D, Sparkman A, et al. Natural history of scoliosis in nonambulatory spastic tetraplegic cerebral palsy. PMR. 2011; 3(1):27-32

48. Gorter JW, Ketelaar M, Rosenbaum P, Helders PJ, Palisano R. Use of the GMFCS in infants with CP: The need for reclassification at age 2 years or older. Dev Med Child Neurol. 2009; 51(1):46-52.

49. Tsirikos Al. Cerebral Palsy: Classification, Etiology and Evolution of Spine Deformity in Children and Adolescents. Current Pediatric Reviews. 2005; 1(2):125-34.

50. Cortés CF, Rubalcava RM. Análisis del cambio en la concentración a través del coeficiente de Gini. Demografía y economía. 1983; 17(4):458-88.

51. Chaves EJ. Distribución y coeficiente de Gini, curva paramétrica de Lorenz sugerida y cálculos. Tendencias. 2003; 4(2):97-123.

52. Campbell V. Chapter 16: The Natural History of Neuromuscular Scoliosis. In: Nnadi EC, editor. Early Onset Scoliosis. New York: Thieme Publishers Stuttgart; 2016. p. 134-40.

53. Loeters MJ, Maathuis CG, Hadders Algra M. Risk factors for emergence and progression of scoliosis in children with severe cerebral palsy: a systematic review. Dev Med Child Neurol. 2010; 52(7):605-11.

54. Hagberg B, Hagberg G, Olow I, von Wendt L. The changing panorama of cerebral palsy in Sweden. VII. Prevalence and origin in the birth year period 1987-90. Acta Paediatr. 1996; 85(8):9549-60

55. Castellanos GRR. Asociación entre factores perinatales y neonatales de riesgo y parálisis cerebral. Rev Cubana Pediatr. 2010; 82(2).

56. Quintana NIV, Zárraga MY, Luis J, Ávila Reyes R. Recién nacidos con bajo peso; causas, problemas y perspectivas a futuro. Bol Méd Hosp Infant Méx. 2004; 61(1):73-86.

57. Senaran H, Shah SA, Presedo A, Dabney KW, Glutting JW, Miller F. The risk of progression of scoliosis in cerebral palsy patients after intrathecal baclofen therapy. Spine (Philadelphia Pa 196). 2007; 32(21):2348-54

58. Garg S, Engelman G, Yoshihara H, McNair B, Chang F. The relationship of gross motor functional classification scale level and hip dysplasia on the pattern and progression of scoliosis in children with cerebral palsy. Spine Deform. 2013; 1(4):266-71.

59. Porter D, Michael S, Kirkwood C. Patterns of postural deformity in non-ambulant people with cerebral palsy: what is the relationship between the direction of scoliosis, direction of pelvic obliquity, direction of windswept hip deformity and side of hip dislocation? Clin Rehabil. 2007; $21(12): 1087-96$

60. Crawford L, Herrera-Soto J, Ruder JA, Phillips J, Knapp R. The Fate of the Neuromuscular Hip after Spinal Fusion. J Pediatric Orthop. 2017; 37(6):403-8. 